\title{
Hierachy of Management Strategies in Improving Traditional Fishers's Welfare at Coastal Area of Manado Bay, North Sulawesi, Indonesia
}

\author{
Daisy.I.E Sundah ${ }^{1}$, Soemarno ${ }^{2}$, Agus Suman ${ }^{3}$, Paulus Kindangen ${ }^{4}$ \\ ${ }^{I}$ Graduate Program of Environmental Science and Technology, The University of Brawijaya, Malang, \\ Indonesia, and The Department of Business Management, Manado State of Polytechnic, Manado,Indonesia. \\ ${ }^{2}$ Faculty of Agriculture, The University of Brawijaya, Malang, Indonesia, \\ ${ }^{3}$ Faculty of Economics, The University of Brawijaya, Malang, Indonesia and \\ ${ }^{4}$ Faculty of Economics, The University of Sam Ratulangi, Manado, Indonesia .
}

\begin{abstract}
This research is conducted to analyze management strategy in improving traditional fishers' welfare. Firstly, probability sampling is used to determine the sample of 125 fishers and collected by using questionnaire. Data are analyzed quantitatively using 'SWOT (Strengths Weaknesses Opportunities Threats) to formulate the management strategies. Secondly, non probability sampling is used to identify 16 informants and collected data by using 'Analysis Hierarchy Process ('AHP')' questionnaire. It is analyzed by using 'AHP' (analytical hierarchy process) program to identify priorities of variables, indicators and strategies which effectively affect the improvement of traditional fisher's welfare. Results show that the variables and indicators improvement of the traditional fishers' welfare are: (1) environmental change, (2) adaptive behavior, and (3) coastal development. Management strategies to improve fishers' welfare include (1) human resource development; (2) income generating/investment and business development; (3) infrastructure development; (4) tourism development; and (5) law and regulation enforcement.
\end{abstract}

Keywords:management strategies, fisher's welfare, analyitical hierarchy process (AHP), strengths weaknessess opportunities threats (SWOT), coastal management.

\section{INTRODUCTION}

Indonesia is a country of islands with coastal area spread through $81,000 \mathrm{~km}$. Therefore, development and the empowerment of coastal community, are just two inseparable sides of coin, and also important to integrate in improving the welfare of the community in Indonesia. There are several research focused on coastal area community such as: the research of coastal development in Manado Bay, Indonesia has found that coastal development, environmental change, and adaptive behaviour affect traditional fishers' welfare [1]. In line with such issues, it is also found that there is a potential positive and negative impacts on Tuvalu Coastal Fisheries Development [2]. Another result indicates that there is a very significant change against coastal community life pattern, mainly to non-fisher community [3]. Moreover, it is found that the coastal development in Manado Bay, Indonesia causes fishers not only as the subject of development in their demographic region [4]. This is also supported by statistic data showing that the poor in the coastal area of Manado City is assigned into categories of very poor (10\%), poor (28\%), and almost poor (62 \%) [5].

Poverty is not surprising trend in the fisher community group in Indonesia [6]. Many complex reasons are stayed behind fisher poverty, such as fluctuated fishing season, limited human resource's capability, limited capital and access, exploitative fish trade network against fisher, and fishing modernization which encourages further excessive draining of marine resources (overfishing) [7]. Indeed, coastal development has begun since 1990s but it brings also a logic consequence as the degradation of coastal environment increases [8]. Environmental degradation has impacted the fishers negatively because sea and coast are where they suppose to work. However, fishers have very determined social and cultural characteristics such as: very strong relationship structure of patron and client; high work ethos; ability to use self-competence and optimal adaptation; to be competitive and achievement-oriented; to be appreciative to skill, rich and life success; to be open and expressive; to have high social solidarity; and to have sex -based work division system (which is sea for male and land for female) despite their consumptive behavior [9]. Positive characteristics possessed by fishers help them to struggle and survive in the change of their 
environment. Therefore, it is found that fisher community at Benua Baru Ilir Village, South Sulawesi, is considered as welfare [6].

The empowerment of fisher community is a new paradigm that is applied for the improvement of coastal community's welfare. Positive fisher characteristics may lead to opinion that the management of coastal area shall involve "stakeholders" in the coastal area such that the goal of coastal area development is easily achieved [10][11][12]. However, the participation of 'stakeholders' in the planning and management of coastal natural resources must be cautiously interpreted and clearly defined because it is possible that priorities determined by 'stakeholders' are not reliable to implement due to different knowledge and limited technical aspect [13].

Coastal development of Manado Bay can influence the environmental change of traditional fishers, either positive or negative such as: job opportunity is one positive impact for traditional fishers; the slum is used to a daily scene at coastal area in Manado Bay, but it gradually disappears; the danger of great wave at certain season and what is considered "rob" against traditional fishers' settlement have been minimized by coastal area development; however, coastal area development of Manado Bay has influenced fisher behavior in adapting to the new built environment, either in their fishing system or their job alternative to improve their welfare [1].

Three objectives of research are determined: firstly, it is to identify strengths, weaknesses, opportunities and threats, and also formulate strategies to improve traditional fishers' welfare. Secondly, it is aimed to identify the priority of variables and indicators that influence the traditional fishers' welfare. Finaly, research attempts to acknowledge the priority of strategies to improve traditional fishers' welfare. It is expected that research will contribute the insight of the government of North Sulawesi Province, Indonesia and especially the government of Manado City in setting and determining the strategy and policy related to coastal development, especially strategic efforts to improve traditional fishers' welfare and the spatial order of coastal area in Manado Bay.

\section{LITERATURE REVIEW}

Management comes from the verb of "to manage" which means arranging or managing. Management is a very important part of the life of every human being in this world. In reality, everyone has management practice in everyday life, either individually, familiy, socially, at work, or other activities. Whether consciously or not, management has been practiced by every human being individually and/or groups that are driven by the goal to be achieved. Desired goal/set will motivate each individual and/or group to perform a series of activities in order to achieve desired goal/set. The increasing age is getting someone more management experience gained in his/her life. Both good and/or bad experience would enrich management experience achived in his/her life and that any actions to be taken become increasingly focused on goals achievement effectivly and efficiently.

Some definitions of management have been raised by experts in the field of management. It is explained that management is a series of activities (planning and decision making, organisation, leadership, and controlling) which directed at the organisational resources (humanresources, finance, physical, and information) in order to achieve organizational goals effectively and efficiently [14]; It is also stated that managemeng is a process of designing and maintaining an environment where individuals work together in groups to acheive certain goals efficiently [15]; It is also explained as a process or framwork that involves the guidance or direction of a group of people toward organizational goals [16]; Another interesting definition says that management is an art to complete the activities through other people [17]. Based on these definitions, it can be concluded that management contains the following elements:

- Has the objectives to be achieved by an organization.

- Contains elements of art which means there is no specific formula to achieve the organization's goals because each organization has defferent characteristics and therefore the achievement of organization's goals will be achieved differently.

- Contains elements of cooperation which means that a set of goals has to be achieved cooperatively by people in the organization.

- Consists elements of process which means that management will take place continuously in the planning, organizing, directing, and controlling over resources effectively and efficiently to achieve its intended purpose.

The development of science and technology led to the development of products and services that can satisfy the needs and desires of the community. As a result, each organization will compete to produce goods and services that can satisfy the needs and desires of the community. Therefore, each of organization's step in the development used to be able to produce optimal products and services. This can be achieved if it supported by an adequate material and non-material resources namely: human resources, equipment, capital, method, and market. In 21st century, the quality of human resources should be viewd as a whole includes aspects of physical and non-physical qualities which aims to improve the welfare, security and justice of the society. Therefore, the 
theory of human development in the new paradigm prioritze human dimension as a major subject in the development of human dignity and integrity.

Strategic management is a process of combining art, skill, and knowledge and to which must be controlled by the organization's management to observe, understand, and analyzing the organization as a system that always unites in harmony with its environment in order to achieve a competitive advantage [18]. It is a series of managerial decisions and actions that determine the performance of the organization in the long term [19]. It is also a function of leaders decisions who want to connect the three main factors namely: the environmental strengths, resources capability, and expectations and goals [20]. The simplicity of the management strategy's framework is presented in Fig. 1 as follows:

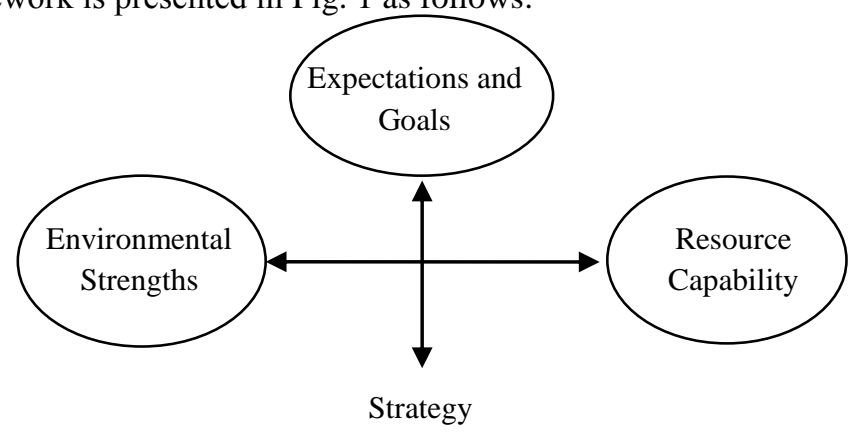

Fig. 1 Management Strategy

The simplicity Fig. 1 implies the complexity of organizational environment. Leader will face a high degree of uncertanty that are difficult to understand and predict systematically. Nevertheless, leaders know the influences and conflicting expectations that comes from stakeholders in the implementation who can make clear the achievement of the organizational goals. Therefore, strategic leaders must find ways of adjustment to the expectations and targets to be achieved by the organization. Resource capability is sometimes not entirely clear. What is seen as a strengths by leaders can become a weaknessess and inflexibility in the environmental change. In fact, if leader is clear about the environment, expectations and objectives of the stakeholders, and the resources capability, these do not mean that these three factors have been matched. These three factors could be heading in a different direction [20]. Other strategic management process introduces 4 basic elements, namely: environmental observation, strategy formulation, strategy implementation, and evaluation and controlling [19]. This is illustrated in Fig. 2 as follows:

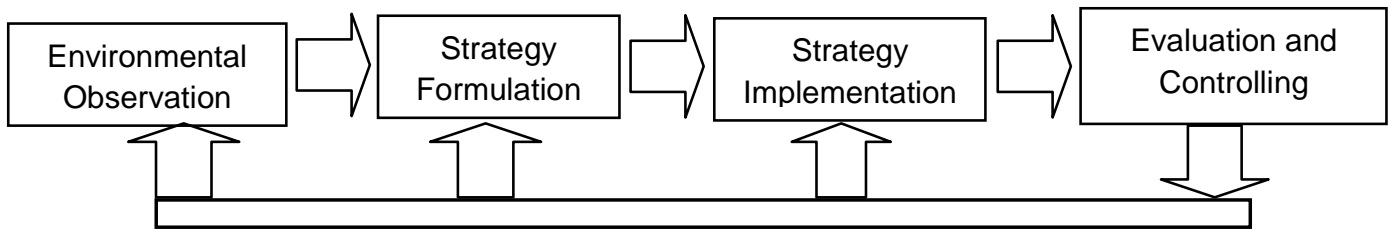

Fig. 2 Basic elements of strategic management process.

Fig. 2 shows the activities begin from the observation of the environment to the evaluation and controlling. Management observe the external environment to analyze the opportunities and threats, and observe the internal environment to analyze the strengths and weaknessess. The most important factors for the organizational future are referred to as strategic factors namely: strengths, weaknessess, opportunities, and threats (SWOT) [19].

Management strategy of the organization is the pattern of decisions relating to the important factors that are used as a guide for organizations in dealing with the environement, affecting the internal organization both structure and process, and affecting the performance of the organization [21]. Therefore, management strategy is the key success of organization's performance [22]. That is because the management strategy is an overall plan which describes the competitive position of an organization. Quality management strategy is a strategy which is built with the formulation implementation, and evaluation of a quality strategy [23]. It can be argued that each organization will have a sustainable competitive advantage in achieving the desired objectives by implementing the strategic management process. Management strategies will certainly vary according to the organization's environment. Strategy planning models sometimes do not accomodate variations and complexity of organization's phenomenon [24]. Therefore, the process of developing a good strategy should be started from the belief that the strategies are in accordance with the quality of formulation's process, and clarity and firmness of implementing the management strategy [25] or it could be argued that how the management strategies were raised [24]. It can be concluded that a key factor in implementing the strategy management process is 
organizational leaders who are able to built systematic adaptation of organisation's environment and the organisation's vision and mission.

\section{METHODOLOGY}

Method of research is combining between quantitative and qualitative methods such that more comprehensive, valid, reliable and objective data are obtained [26]. Quantitative approach is used in SWOT Analysis which involves 125 traditional fishers in Manado Bay. Data collection techniques is probability sampling which using simple random sampling. The determination of sample is by visiting respondents randomly in the morning or afternoon before they do fishing activity. Data are collected to identify strengths, weaknesses, opportunities, and threats in the matrix analysis of SWOT (Strengths, Weaknesses, Opportunities, and Threats), and to illustrate the alternatives of strategies and activities to improve traditional fishers' welfare at coastal area in Manado Bay. Data collection with qualitative approach involves interviews to 16 informants (4 public figures, 8 fishers, and 4 government employees). Quantitative analysis uses Analytical Hierarchy Process (AHP) questionaires. Sampling technique in this qualitative research is nonprobability sampling using sampling technique of purposive sampling. The selected informants in this research include the long experienced fishers, public figures and government employees. Their inputs are needed to understand their perception of variables and indicators, and to figure out strategy alternatives to empower traditional fishers at Manado Bay. Data from the 16 informants do not concern with the quantity of informants but the quality of informants such that the data obtained from AHP questionnaire will produce high objectivity rate based on the knowledge, definition, and trust of individual about their attitude (cognitive) object because of their experience. Every informant will compare how important is variables/indicators/strategies alternatives with others which are more effective influencing/empowering traditional fishers to improve their welfare. The comparative assessment scale by every informant starts from 1 to 9 [27]. The detail is explained in Table 1 as follows:

Table 1 Matched Comparison Scale

\begin{tabular}{|c|l|l|}
\hline $\begin{array}{c}\text { Level of } \\
\text { Importance }\end{array}$ & \multicolumn{1}{|c|}{ Definition } & \multicolumn{1}{|c|}{ Description } \\
\hline 1 & $\begin{array}{c}\text { Both elements are important. } \\
\text { One element is quite bit more } \\
\text { important than other. }\end{array}$ & $\begin{array}{l}\text { Both elements are } \\
\text { contributing equally. }\end{array}$ \\
$\begin{array}{c}\text { Experience and consideration } \\
\text { are supporting slightly to one } \\
\text { element above the other. }\end{array}$ \\
\hline 5 & $\begin{array}{l}\text { One element is very important } \\
\text { than other. }\end{array}$ & $\begin{array}{l}\text { Experience and consideration } \\
\text { are supporting strongly to one } \\
\text { element above the other. }\end{array}$ \\
\hline 9 & $\begin{array}{l}\text { One element is strongly } \\
\text { important than other. } \\
\text { supported, and dominant in } \\
\text { practice. } \\
\text { One element is absolutely } \\
\text { important than other. } \\
\text { one element against other has } \\
\text { highest strictness rate. }\end{array}$ \\
\hline $2,4,6,8$ & $\begin{array}{l}\text { Values between two } \\
\text { considerations are closely } \\
\text { related. }\end{array}$ & \begin{tabular}{l} 
between both considerations. \\
\hline
\end{tabular} \\
\hline
\end{tabular}

\section{RESUlt AND DiscuSSION}

\subsection{Description of Coastal area in Manado Bay}

Coastal area in Manado Bay is supported with various economic activities such as offices and shopping centers such as Mega Mall, Manado Town Square (ManTos), Bahu Mall, Manado Trade Centre (MTC), Information Technology Center (ITC); food-related business or restaurants, Private Hospital (Siloam); fish auction site, harbor, and traditional market 'Bersehati'. Along the coastal area in Manado Bay is the location of research which covers some subdistricts such as Malalayang, Sario, Wenang, Tuminting, and Bunaken (Figure 1). One of these 5 locations is Bunaken Subdistrict, which is located at northern of Manado Bay. It represents coastal area protected by the government of Indonesia because this area is the part of "Bunaken" National Marine Park. There are 5 rivers with their orifice at the sea around coastal area in Manado Bay. These rivers include Tondano River $(11 \mathrm{Km})$; Bailang River $(17.9 \mathrm{Km})$; Sario River $(6.72 \mathrm{Km})$; Malalayang River (4.80 $\mathrm{Km})$; and Tikala River (7.12 Km) [5]. Research location is shown in Fig 3: 


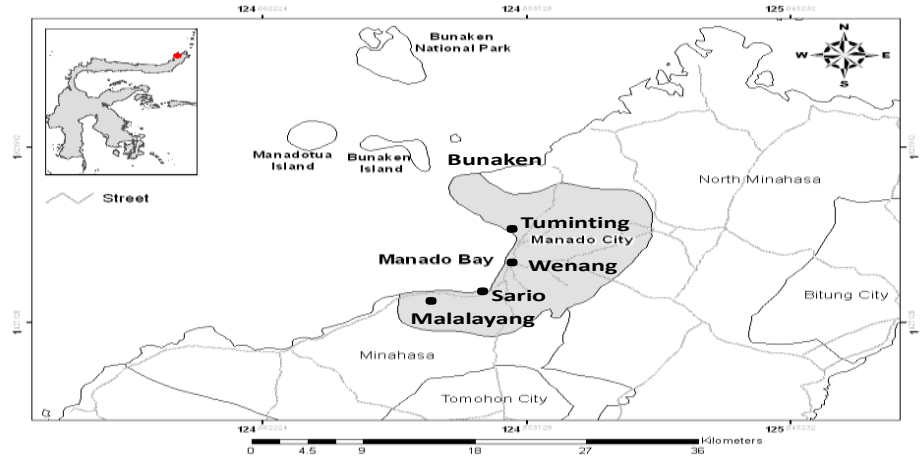

Fig. 3 Geographic Site of Manado Bay, North Sulawesi, Indonesia

Five rivers are ended in similar orifice at Manado Bay such as Tondano; Bailang; Sario; Malalayang; and Tikala river. The development at coastal area may prevent the sea from recovering itself fast. Trashes brought by these rivers may have been thrown by wave to the land, but coastal area development can force this garbage returned to the sea center because the land cannot anymore accommodate it. Finally, trashes are just piled up at certain areas on the land. Fig. 4 indicates these trashes on the land of coastal area of "Bitung Karangria". Fishers who live in this area are familiar with this condition such that when they do fishing, these trashes are just ignored.

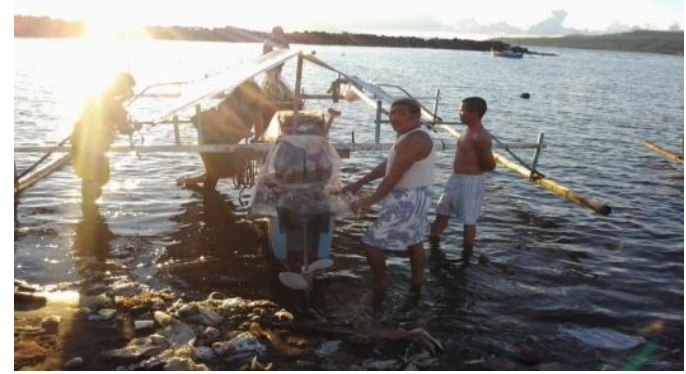

Fig. 4 Trashes at the location of Bitung Karangria, Manado

Fig. 4 indicates that community awareness of North Sulawesi Province to discard trashes in the right place is very low. Traditional fishers perceive that physical environment of the sea around coastal area in Manado Bay is very dirty and disgusting. It may influence badly Bunaken National Marine Park. Traditional fishers around coastal area in Manado Bay are still using various fishing methods such as fishing rod, fish net, and fish trap.

\subsection{Informants Profile}

Informants involved in this research include public figures and government employees who understand the work of fisher and the fishers. There are 16 informants (4 public figures, 8 fishers, and 4 government employees). Data of research informants are as following:

Table 2 Profile of informants group

\begin{tabular}{|c|c|c|}
\hline $\begin{array}{l}\text { Name of } \\
\text { Group }\end{array}$ & No & Job Description \\
\hline \multirow{4}{*}{$\begin{array}{l}\text { Public } \\
\text { Figures }\end{array}$} & 1 & $\begin{array}{l}\text { Navigation district employees of the government of Bitung } \\
\text { City who live at research location. }\end{array}$ \\
\hline & 2 & 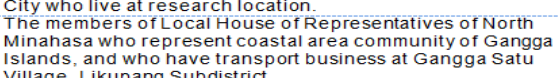 \\
\hline & 3 & 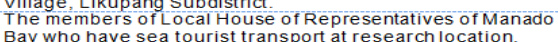 \\
\hline & 4 & $\begin{array}{l}\text { Private and NGO with great care to fisher community and } \\
\text { with the domicile at research location. }\end{array}$ \\
\hline \multirow[t]{8}{*}{ Fishers } & 5 & Traditional fishers. \\
\hline & & Traditional fishers as the member of fisher association. \\
\hline & 7 & Traditional fishers with alternative job as ojek. \\
\hline & & but still do fishing using "pajeko" and "purse seine". \\
\hline & 9 & $\begin{array}{l}\text { Traditional fishers as the head of fisher association and } \\
\text { who work as government employee. }\end{array}$ \\
\hline & 10 & Traditional fishers. \\
\hline & 11 & Traditional fishers / retiree of civil servant. \\
\hline & 12 & Traditional fishers as the head \\
\hline \multirow[t]{4}{*}{$\begin{array}{l}\text { Government } \\
\text { Employees }\end{array}$} & 13 & $\begin{array}{l}\text { The coordinator of fishery extension (Food Security and } \\
\text { Extension Agency) }\end{array}$ \\
\hline & 14 & $\begin{array}{l}\text { Head of Section of Organizational Development } \\
\text { (The Official of Marine and Fishery of Manado City) }\end{array}$ \\
\hline & 15 & $\begin{array}{l}\text { Head of Section of Natural Resource Development and } \\
\text { Protection (The Official of Marine and Fishery of Manado }\end{array}$ \\
\hline & 16 & $\begin{array}{l}\text { Head of Section of Human Resource (The Official of Marine } \\
\text { and Fishery of Manado City) }\end{array}$ \\
\hline
\end{tabular}

Source of Data: Result of data processing, 2013 
Table 2 shows that public figures are a group of people who live together with fishers and with great care to the life of traditional fishers at coastal area in Manado Bay. Fishers are a group of people who have long experience being as fishers, and even one of them has a job as traditional fishers and been successful to develop fish-based restaurant. Government employees are a group of people who work at fishery field and acquaint closely with traditional fishers, either through their function as the extension worker in fishery field or from their competence in the fishery field.

\subsection{Method to Determine the Levels at Traditional Fishers' Welfare Hierarchy}

Variables and indicators influencing traditional fishers' welfare and strategy alternatives at welfare hierarchy of traditional fishers at coastal area in Manado Bay are deployed in Fig. 5.

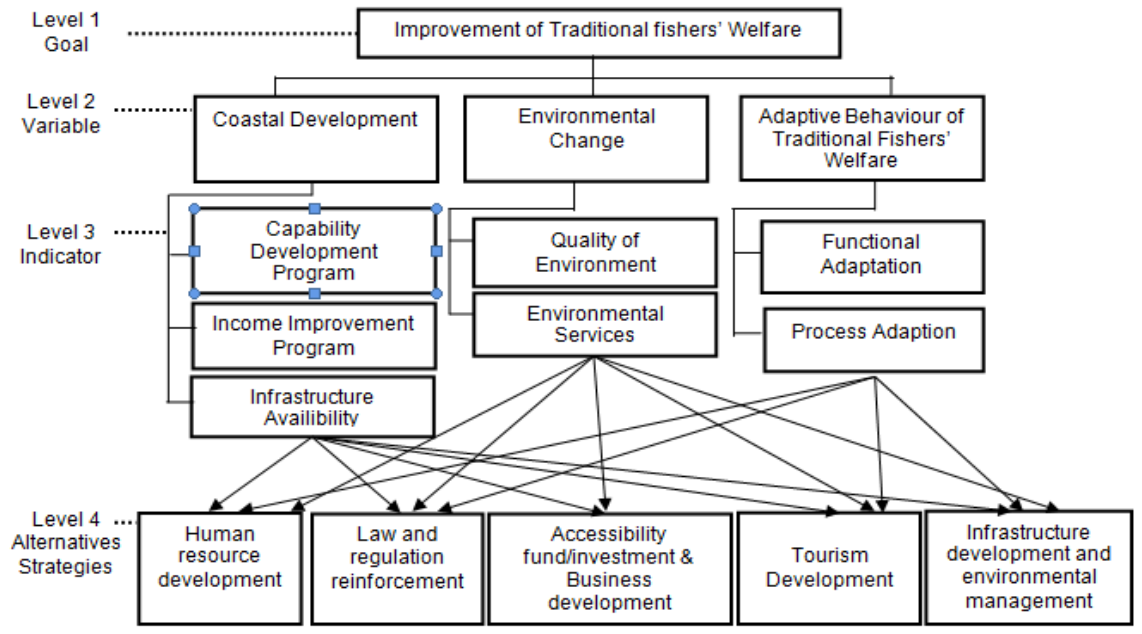

Fig. 5 The hierarchy of management strategies in improving traditional fishers' welfare at coastal area of Manado Bay, North Sulawesi, Indonesia

Fig. 5 shows that the objective of the development at coastal area in Manado Bay is the improvement of community welfare, including that of traditional fishers. The second and third level of hierarchy has been analyzed based on Structural Equation Modeling (SEM) [1]. It is explained that variables and indicators influencing traditional fishers' welfare are: firstly, variable of coastal development with indicators of human resource capability development program, income improvement program, and infrastructure availibility; secondly, variable of environmental change with indicators of environmental quality and environmental services; and thirdly, variable of adaptive behavior with indicators of functional adaptive behavior and processual adaptive behavior.

SWOT Analysis involves two stages. First stage is collecting the data, and second stage is the implementation of SWOT analysis. Questionnaire data are obtained from 125 respondents using variables and indicators used within SWOT (Strengths, Weaknesses, Opportunities, and Threats) by identifying internal environment (strengths and weaknesses) and external environment (opportunities and threats) to improve traditional fishers' welfare. Based on the identification of SWOT, strategies are analyzed by using four quadrants of SWOT strategies, which include "strengths-opportunities" strategy, "strengths-threats" strategy, "weaknesses-threats" strategy, and "weaknesses-opportunities" strategy [28]. It is described in Fig. 6 as following:

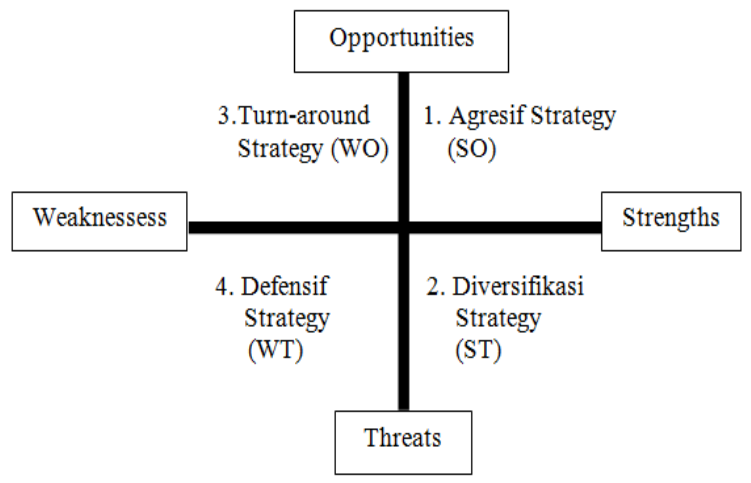

Fig. 6 SWOT Analysis 
Quadrant 1 to 4 is explained as following:

Quadrant 1. It shows a very benefiting situation where opportunities and strengths exist such that both can be used. The strategy to apply is an aggressive strategy or Strategy "SO" (Strengths-Opportunities). Indeed, Strategy "SO" (Strengths-Opportunities) represents a strategy to select benefit by using whole powers to use the opportunities.

Quadrant 2. Although facing various threats, internal strengths are still retained. The recommended strategy is using these strengths for long-term opportunities through diversification strategy, or called as Strategy "ST" (Strengths-Threats). Strategy "ST" (Strengths-Threats) refers to a strategy to deploy/to use strengths by using these strengths to avoid from threats or to cope with threats.

Quadrant 3. Opportunities may be very enormous, but there are internal barriers/weaknesses in other spot. The suggested strategy is to minimize internal weaknesses such that better opportunities cannot be missed. This strategy is called as Strategy "WO" (WeaknessesOpportunities). Strategy "WO" (Weaknesses-Opportunities) is a strategy to use opportunities by eliminating or minimizing weaknesses.

Quadrant 4: It is a very bad situation because internal weaknesses and threats must be faced. The strategy to be implemented is defensive strategy or Strategy "WT" (WeaknessesThreats). Strategy "WT" (Weaknesses-Threats) is a strategy to control or to cope with threats and to attempt of minimizing weaknesses.

Based on the identification of variables and indicators, and the empowerment strategy to use SWOT matrix, it is then "stakeholders" (traditional fishers, public figures, and government employees) as the research informants to assess, to prioritize and to show the more effective variables and indicators to be improved actively through AHP questionnaire.

\subsection{The Formulation of Strategies in improving Traditional Fishers' Welfare}

Strategy is an action that is continually improved based on perspective of "what" is expected by community in the future. SWOT analysis is one way to determine which strategy that is desired to improve the traditional Fishers' welfare. The following is a process of SWOT analysis.

\subsubsection{The identification of strengths and weaknesses of internal indicators}

Internal indicators influencing traditional fishers' welfare are explained in Table 3 which also identifies strengths and weaknesses. Respondents state that most of them have long experience as fisher. Most respondents choose being fisher as parental legacy and recall that the change of their life environment forces them to participate into skill training to improve their capability. They understand that science and technology have been advanced and developed so quickly. Any meetings and assemblies with other will improve their insight and knowledge. It is shown by the joining of respondents into fisher association organization. Respondents, indeed, have high motivation to manage well their occupation as fisher and most of them have adapted to the modern fishing which is environmental friendly.

Table 3 The identification of internal Indicators

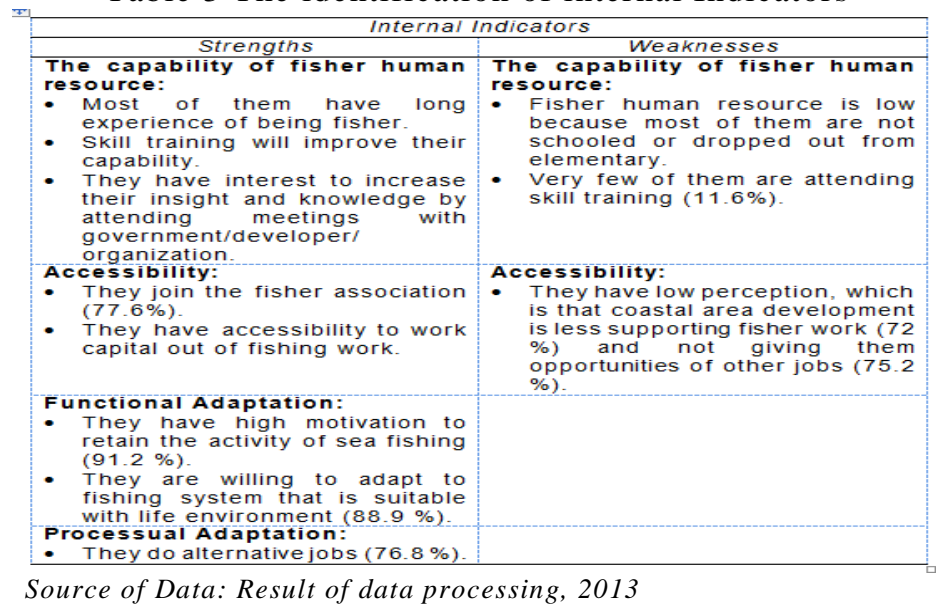

Most respondents have had alternative jobs to meet the subsistence. It is evident because many job opportunities are available at coastal area in Manado Bay. Many weaknesses are also 
identified, however. Most respondents have low education and many of them are not participated into any skill trainings. They express low perception, stating that the coastal area development of Manado Bay will not support them and that this development is not giving them opportunities for jobs out of fisher.

\subsubsection{The identification of external opportunities and threats indicators}

Besides internal indicators, there are external indicators influencing traditional fishers' welfare as explained in Table 4:

Table 4 The identification of external indicators

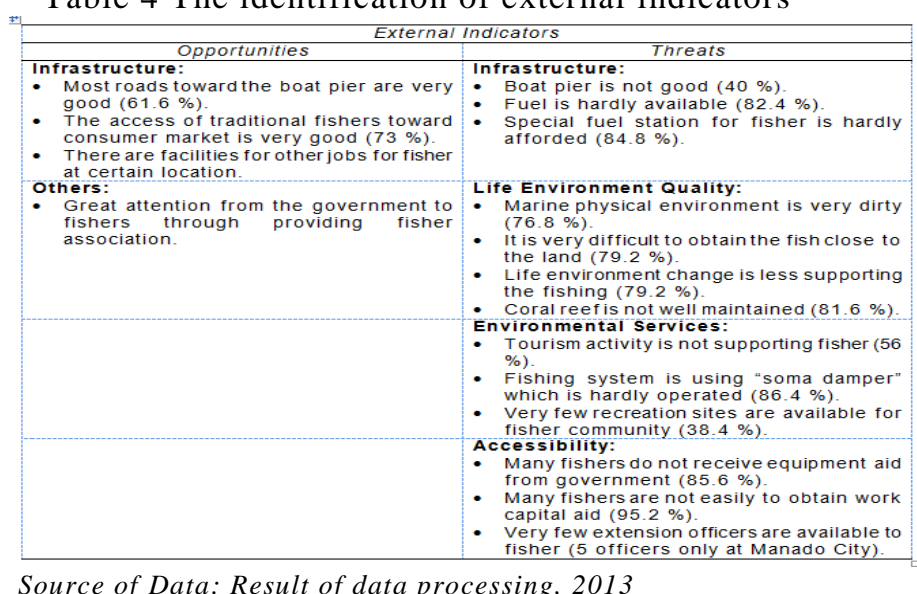

Table 4 has identified many opportunities from external indicators among other is wide job opportunities for fishers out of fishing activity. Work facilities have been provided by government at certain places for fisher to develop their alternative job. Some programs are delivered by government through The Official of Fishery and Marine of Manado City to hand over contribution to fisher associations. Coastal area development of Manado Bay is by providing infrastructure and facilitating the access to consumer market. Certain places may be hardly developed, such as Bahowo Village, in the north edge of Manado City, at Bunaken Subdistrict.

Some threats are also identified. Some of them are less reliable boat pier and limited number of fishing boats at Manado Bay. The difficulty to obtain "fuel" and to afford "fuel station" shall be threats for fisher in doing their job. Result of research indicates that environmental change at coastal area in Manado Bay does not change most traditional fishers' welfare at coastal area in Manado Bay because of such as dirty physical environment, the difficulty to obtain fish close to the land, and less maintained coral reef at certain area. Only very few respondents have reported that environmental change is less supporting fishers, such as the availability of facilities and job opportunities, the protection from wave to fisher settlement, and the reduction of slum at coastal area. Most respondents also feel that environmental service is not less supporting fishers as shown by very limited and less coordinated tourism, the difficulty of traditional fishers to do fishing using fish net ("soma dampar), and the limited recreation for fisher and family at certain locations. It is also indicated that most respondents have not yet obtained equipment and work capital aids to support fisher work and the limited number of extension officer may obstruct the activities of directing and counseling of fisher association. All of them are threats that can obstruct the achievement of objective to improve traditional fishers' welfare.

\subsubsection{SWOT Analysis}

Empowerment concept may rely on the egalitarian self-support principle because it is very relevant to community empowerment [29]. Fig. 7 shows that SWOT Analysis is useful to formulate the strategy to improve traditional fishers' welfare at coastal area in Manado Bay shown as following: 


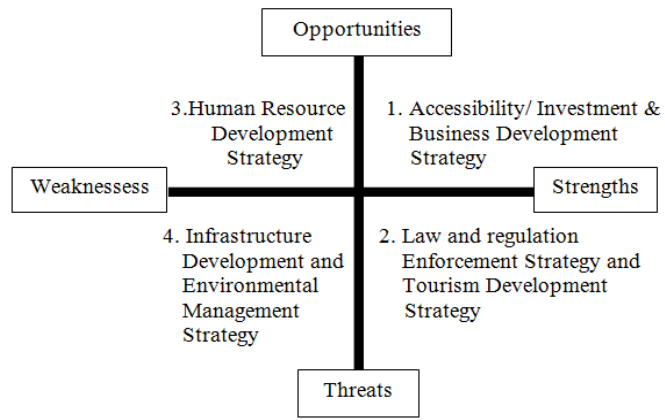

Fig. 7 SWOT Analysis as the strategies for improving fishers' welfare at Manado Bay, Indonesia

SWOT Analysis refers to an analysis to determine the most appropriate strategy. SWOT Analysis described in Fig. 7 is explained as following:

1. Strategy SO (Strengths-Opportunities) is a strategy to choose profits by using strengths and opportunities. Strengths are the base capital to use opportunities. Fig. 7 shows that selecting strategy which is suitable to capital/investment accessibility and business development is itself an important strategy. It must be also useful for the benefit of traditional fishers. Some strengths and opportunities are developed for better profit. Obtaining work capital is facilitated. The supply of information, knowledge and technology about business development is important to increase fisher welfare. The important activities to conduct are counseling with fisher association such that fisher association can be more effective and establishing the counseling for the cooperative and the development of fishers' welfare based on their interest and demand.

2. Strategy ST (Strengths-Threats) represents a strategy to exercise strengths by using it to avoid from threats. Fig. 7 indicates that strategies of enforcing the law and regulation and strategies of developing tourism are those that must be easily implemented. Related to the legal enforcement, the strategies include the socialization, the application of law and regulation on environment, the management of environment at coastal area in Manado Bay, and the improvement of fuel supply for traditional fishers and other user of coastal area. The strategies related to tourism development must be those that promise for the welfare of traditional fishers at coastal area in Manado Bay.

3. Strategy WO (Weaknesses-Opportunities) refers a strategy to use opportunities by eliminating weaknesses and to optimize opportunities. Fig. 7 shows that strategy of human resource development is important to minimize weaknesses and to use available opportunities. Activities related to this strategy are the skill training to increase the interest and demand of traditional fishers, the education of modern fishing technique, entrepreneurship, and the socialization of coastal area development which is adapting to the demand of traditional fishers.

4. Strategy WT (Weaknesses-Threats) is a strategy to control threats by minimizing weaknesses to avoid from threats. Fig. 7 indicates the strategies related to infrastructure development may involve improving boat pier and developing tourism infrastructure to support traditional fishers' work. Strategies related to the improvement of environment may include minimizing the negative impact by socializing beach and sea cleanliness to community and emphasizing better management of environment, and empowering the positive impact to traditional fishers through developing small works or business developement and tourism work.

\subsection{Analytical Hierarchy Process (AHP)}

'Analytical Hierarchy Process' (AHP) is developed by Thomas Saaty in 1971 [30]. The selection of analysis tool is based on consideration that analytical hierarchy process is a device or a model of decision-making with human perception as main input. AHP represents a method to solve a complex problem of the groups in hierarchy manner. AHP, indeed, uses the weighting of variables and indicators based on human perception such that it may describe the actual condition. Research is conducted to understand variables and indicators, and which strategy that influences or determines effectively to improve traditional fishers' welfare and sustainable coastal area in Manado Bay. The greater weight of variables /indicators/ strategies may mean that these variables/indicators/ strategies are more important than others in influencing/improving traditional fishers' welfare. Analytical Hierarchy Process (AHP) helps to provide alternative priority and is also helpful to track inconsistency in the consideration and preference of a respondent [27]. (Saaty, 1993). Indicators in the management of coastal area are assigned in categories of biology, life 
environment, social, economical, political and demand [31][32]. These indicators are also related to other multidiscipline indicators Variables and indicators, and strategies explained so far, are indicated at Table 5 as following:

Table 5 The description of variables, indicators and strategies

\begin{tabular}{|c|c|}
\hline $\begin{array}{l}\text { Goal, variables, } \\
\text { indicators and } \\
\text { strategies }\end{array}$ & Description \\
\hline $\begin{array}{l}\text { Goal: Variables of } \\
\text { Welfare }\end{array}$ & $\begin{array}{l}\text { Social welfare is a condition when the material, spiritual and social } \\
\text { demands of citizen are met such that they can live reliable and be self- } \\
\text { developed such that the social function is implemented (Act No.11 of } \\
\text { 2009). }\end{array}$ \\
\hline $\begin{array}{l}\text { Variable of Coastal } \\
\text { Development }\end{array}$ & $\begin{array}{l}\text { Coastal area development of Manado Bay is measured from } 3 \\
\text { indicators. }\end{array}$ \\
\hline $\begin{array}{l}\text { 1. Human resource } \\
\text { development }\end{array}$ & $\begin{array}{l}\text { It measures the development of fisher capability to improve the } \\
\text { capability of traditional fishers. }\end{array}$ \\
\hline 2. Accessibility & $\begin{array}{l}\text { It measures the activities to facilitate traditional fishers to improve their } \\
\text { welfare. }\end{array}$ \\
\hline 3. Infrastructure & It measures the facilities which support fishers other business. \\
\hline $\begin{array}{l}\text { Variable of } \\
\text { Environment }\end{array}$ & $\begin{array}{l}\text { It is life environment surrounded the life of fisher community, including } \\
\text { physical, social and economical environments of fisher community. }\end{array}$ \\
\hline $\begin{array}{l}\text { 4. Quality of } \\
\text { environment }\end{array}$ & It measures the degree of fulfilling the base demand of environment. \\
\hline $\begin{array}{l}\text { 5. Environmental } \\
\text { services }\end{array}$ & $\begin{array}{l}\text { It measures the function of coast and sea areas which support the } \\
\text { fishers' work. }\end{array}$ \\
\hline $\begin{array}{l}\text { Variable of Adaptive } \\
\text { Behavior }\end{array}$ & $\begin{array}{l}\text { It is the behavior to adapt to physical environment ecosystem of sea } \\
\text { and social environment around. }\end{array}$ \\
\hline 6. Functional adaptive & $\begin{array}{l}\text { It is a response from fisher community to maintain stable condition by } \\
\text { adapting themselves based on theirjob. }\end{array}$ \\
\hline $\begin{array}{l}\text { 7. Processual } \\
\text { Adaptive }\end{array}$ & $\begin{array}{l}\text { It is a behavior system which is made due to human adaptation to the } \\
\text { change of environment around them by adapting themselves based on } \\
\text { other job other than their main job. }\end{array}$ \\
\hline \multicolumn{2}{|l|}{ Strategies } \\
\hline $\begin{array}{l}\text { 1. Human resource } \\
\text { development }\end{array}$ & $\begin{array}{l}\text { Strategies and programs related to the empowerment and the } \\
\text { development of fisher human resource can support fisher and improve } \\
\text { motivation to adapt with life environment change. }\end{array}$ \\
\hline $\begin{array}{l}\text { 2. Law and regulation } \\
\text { enforcement }\end{array}$ & $\begin{array}{l}\text { Strategies and programs related to the empowerment and the } \\
\text { enforcement of the law shall be submitted and implemented to protect } \\
\text { the rights of fisher and the management of life environment of fisher. }\end{array}$ \\
\hline $\begin{array}{l}\text { 3. Income generating/ } \\
\text { investment and } \\
\text { business } \\
\text { development }\end{array}$ & $\begin{array}{l}\text { Strategies and programs related to the empowerment to the } \\
\text { accessibility to capital/investment and the development of business for } \\
\text { fisher are realized by strengthening/establishing groups and/or fisher } \\
\text { organization or NGO with care for fisher. }\end{array}$ \\
\hline $\begin{array}{l}\text { 4. Tourism } \\
\text { development }\end{array}$ & $\begin{array}{l}\text { Strategies and programs related to the empowerment and the } \\
\text { development of tourism shall be integrated with the development of } \\
\text { fisher work. }\end{array}$ \\
\hline $\begin{array}{l}\text { 5. Infrastructure and } \\
\text { environmental } \\
\text { management }\end{array}$ & $\begin{array}{l}\text { Strategies and programs related to the empowerment and the } \\
\text { development of infrastructure must be required for the development of } \\
\text { fisher work and tourism, and for the improvement of life environment } \\
\text { quality. }\end{array}$ \\
\hline
\end{tabular}

Source of Data: Result of data processing, 2013

\subsubsection{Result of Analytical Hierarchy Process (AHP)}

The assessment of variables and indicators, and also the most effective strategies to improve traditional fishers' welfare at coastal area in Manado Bay, is carried out by asking informants to put their answer to 'Analytical Hierarchy Process (AHP)' questionnaire. The result of analytical hierarchy process is as following:

1. Priorities of variables and indicators according to informant groups

Table 6 shows the priorities assessed by each informant group. It is shown as following:

Table 6 Priority of Variable and Indicator according to group of informants

\begin{tabular}{|c|c|c|c|c|c|c|c|c|c|c|c|}
\hline Variabel & $P F$ & $F$ & $G E$ & Mix & $P$ & Indicator & $P$ & $F$ & $G E$ & Mix & $P$ \\
\hline \multirow{3}{*}{$\begin{array}{l}\text { Coastal } \\
\text { development }\end{array}$} & 0,57 & 0,10 & 0,14 & 0,19 & 3 & Capability HR & 0.23 & 0.33 & 0.17 & 0.27 & 5 \\
\hline & & & & & & Accessibility & 0.18 & 0.42 & 0.52 & 0.38 & 3 \\
\hline & & & & & & Infrastructure & 0.59 & 0.25 & 0.30 & 0.34 & 4 \\
\hline \multirow[t]{2}{*}{$\begin{array}{l}\text { Environmental } \\
\text { Change }\end{array}$} & 0,33 & 0,68 & 0,43 & 0,57 & 1 & $\begin{array}{l}\text { Quality of } \\
\text { Environment }\end{array}$ & 0.73 & 0.90 & 0.84 & 0.85 & 1 \\
\hline & & & & & & $\begin{array}{l}\text { Environmental } \\
\text { services }\end{array}$ & 0.27 & 0.10 & 0.16 & 0.15 & 7 \\
\hline \multirow[t]{2}{*}{$\begin{array}{l}\text { Adaptive } \\
\text { Behaviour } \\
\end{array}$} & 0,10 & 0,23 & 0,43 & 0,23 & 2 & $\begin{array}{l}\text { Functional } \\
\text { Adaptation }\end{array}$ & 0.88 & 0.80 & 0.62 & 0.79 & 2 \\
\hline & & & & & & $\begin{array}{l}\text { Process } \\
\text { Adaptation }\end{array}$ & 0.12 & 0.20 & 0.38 & 0.21 & 6 \\
\hline
\end{tabular}

Source of Data: Result of data processing, 2013

Notes: (PF=Public Figure, $F=$ Fishers, GE=Government Employee, $P=$ Priority)

Public figures have perceived that variable of coastal area development is the main priority to improve community welfare, and it is followed by life environment change and fisher adaptation. They perceive that coastal area development of Manado Bay will give big opportunities to fisher to develop their fishing work. The prioritized indicators are infrastructure, fisher human resource capability, accessibility to obtain aid, and the presence of organizational agencies to empower traditional fishers group. 
Still from public figures, they also perceive that coastal area development will contribute opportunities to the positive life environment change for fishers and other coastal communities. The prioritized indicator of life environment change is life environment quality but indicators related to environment service are also important.

Adaptive behavior of fishers is the main variable priority to improve traditional fishers' welfare while the prioritized indicators of adaptive behavior variables are functional adaptive behavior and processual adaptive behavior. Functional adaptive behavior is by maintaining stable condition by aligning themselves to their job as fisher. This indicator is more important than the adaptation to other job other than being fisher.

Based on fisher perception, main variable priority to improve traditional fishers' welfare is life environment change, especially with the indicators of life environment quality and indicators of environment service. If life environment quality is not improved, it is not possible to improve welfare. It may reduce fish hauling. Second variable priority is fisher adaptive behavior, with functional adaptive behavior as first indicator and processual adaptive indicator as other indicator.

According to fishers' perception, traditional fishers must adapt their work system to the life environment change around them because being fisher is the subsistence for them. Processual adaptive behavior is an adaptation to other alternative activities out of man job. Fishers perceive that increasing optimum fish haul is main thing compared to other alternative job. Alternative jobs are only considered during bad climate or bad season which makes them difficult to do fishing.

Related to the perception of fishers, third variable priority that determines the improvement of traditional fishers' welfare is coastal area development. The prioritized indicators are the indicator of accessibility (with many provisions) to obtain fund/capital, facilities to obtain fuel, and many facilities to support the fisher's work; the indicator of human resource capability; and the indicator of infrastructure.

Government employees admit that the priorities to improve traditional fishers' welfare are life environment change with the indicators of life environment quality and life environment services, and also adaptive behavior with the indicators of functional adaptive behavior and processual adaptive behavior. The final priority of variable is coastal area development with priorities of accessibility and infrastructure.

Together, three informant groups have asserted that the priority variables that determine traditional fishers' welfare are life environment change, adaptive behavior and coastal area development. The prioritized indicators to improve traditional fishers' welfare are life environment quality, functional adaptive behavior, accessibility, infrastructure, human resource capability of traditional fisher, processual adaptation, and environment services.

\section{Priorities of strategies and programs according to informant groups}

Community empowerment must be based on the fundamental principle of community counseling, which is learning from community by acting as the facilitator to create shared-learning for various experiences [33]. Indeed, village with good social capital must have better ability in empowerment, and empowerment model can be more effective if it is underlined by the empowerment of social capital of surround community [34]. Some alternatives of empowerment strategy assessed by informant groups are expected to achieve goals to improve traditional fishers' welfare. It is shown by "analytical hierarchy process" as following:

Table 7 Priorities of Management Strategy for traditional fishers according to informant groups

\begin{tabular}{|c|c|c|c|c|c|}
\hline Strategy & $\begin{array}{c}P F \\
(O I 0,02)\end{array}$ & $\begin{array}{c}F \\
(O I 0,00)\end{array}$ & $\begin{array}{c}G E \\
(O I 0,01)\end{array}$ & $\begin{array}{c}\text { Mix } \\
(O I 0,00)\end{array}$ & $P$ \\
\hline $\begin{array}{l}\text { Human resource } \\
\text { development }\end{array}$ & 0.359 & 0.227 & 0.285 & 0.281 & 1 \\
\hline $\begin{array}{l}\text { Accessibility/Investment } \\
\text { \& Business Development }\end{array}$ & 0.226 & 0.157 & 0.272 & 0.201 & 2 \\
\hline $\begin{array}{l}\text { Infrastructure development } \\
\text { and environmental } \\
\text { management }\end{array}$ & 0.219 & 0.195 & 0.212 & 0.192 & 3 \\
\hline Tourism development & 0.103 & 0.209 & 0.155 & 0.183 & 4 \\
\hline $\begin{array}{l}\text { Law and regulation } \\
\text { enforcement }\end{array}$ & 0.094 & 0.212 & 0.77 & 0.143 & 5 \\
\hline
\end{tabular}

Source of Data: Result of data processing, 2013

Notes: $(P F=$ Public Figure, F=Fishers, GE=Government Employee, $P=$ Priority, OI=Overall Inconcistency) 
Table 7 indicates group of public figures, fishers and government employee that have similar perception that main priority in the strategy of improving traditional fishers' welfare at coastal area in Manado Bay is the development of fisher human resource. Based on the compilation of three informant groups, it is perceived that strategy of accessibility to capital/investment and business development is second priority for the improvement of traditional fishers' welfare. The perception of informant groups also states that in addition to strategy of human resource development which is first priority, strategy of law and regulation enforcement is also second priority such that clean life environment quality is ensured and the right of being traditional fishers is well protected. Even, the strategies of accessibility to capital/investment and business development are positioned in fifth priority, according to informant groups of fisher.

Third strategy, according to this compilation, includes strategy of infrastructure development and life environment improvement. For them, the important thing for their welfare improvement is tourism development strategy. Environmental improvement is only successful if the law and regulation are well enforced. Infrastructure development and environment improvement may be realized by improving boat pier and small harbor, and other facilities, providing structure and infrastructure which support tourism development, and cleaning sea physical environment to produce reliable environment.

Fourth strategy is tourism development strategy. However, informant groups prefer to put this strategy in number three and propose the number four as strategy of infrastructure development and life environment management. Tourism development which is integrated and organized with other activities can support the demand of traditional fishers and therefore, improve traditional fishers' welfare.

Fifth strategy is strategy of law and regulation enforcement. However, informant groups prefer to put this strategy in the second. Traditional fishers consider as the fifth the strategy of accessibility to capital/investment and business development. Strategy of law and regulation enforcement is implemented by keeping cleaned sea physical environment and protecting the right of traditional fishers from illegal fishing and overfishing.

4.5.2. Strategies in improving traditional fishers' welfare at coastal area in Manado Bay, Indonesia According to the perception of informant groups, environmental change is the most primary priority to improve their welfare, either by improving positive impact and minimizing negative impact. The quality of environment must be managed by considering the demand of traditional fishers. Therefore, they can adapt themselves to any environmental changes to obtain easiness in managing their fishing work, to use the provided infrastructure, and to increase their human resource capability. The increased capability will help them to adapt themselves to other alternative jobs which may be useful for their welfare. The supply of environment services can support the fishing work, thus helping them to improve their welfare. Based on the research of [28]. Mohamed (2001), some policy strategies are made by the government of Kuala Lumpur Malaysia to reduce poverty such as environmental improvement, income improvement program, health and welfare service, and the development of trust from self, social and community.

The development of harbor is designed to improve the business and to open work opportunities for community, and therefore, it must influence their income [35]. Another research finds that the failure of local government to provide capital, favorable climate for business environment, or reliable structure and infrastructure, has put the welfare rate of fisher community of Bengkulu far below the welfare indicator, and thus, the community is considered as poor [36].

Traditional fishers must improve their capability through mastering science, knowledge and technology related to fishing and other related fields to open the horizon of thinking of traditional fishers. Human resource has been equipped by knowledge and technology to make them adapting fast to environmental change, either with positive and negative impacts. Job opportunities will give positive impact for coastal area development and it must be positively responded if human resource of fishers is well prepared. Competent traditional fishers can adapt well to any environmental changes in the coast or sea. According to public figures and government employees, reliable human resource can increase fisher to manage their financial resource such that fishing and other works can be well managed. It is consistent to the government program to cultivate reliable human resource in the management of finance such that government aid is used in sustainable manner.

Fisher association shall be improved to a strong institution to help traditional fishers and their families. Data from The Implementing Agency of Extension and Food Security indicate that fisher association and coast women organization have been established at Manado City, which totaled to 103 groups. However, the extension officer is only 5 persons. It seems that the motivation 
of fisher to increase their dignity into self-support and progressive personality must be compensated by the seriousness of the interest parties to provide proportional extension to their demand.

Tourism development strategy is the fourth development strategy priority which is considered very supporting to the improvement of traditional fishers' welfare. One of the research has found that the competence of facilitator and the supporting factors will give obvious influence on the change of community behavior [37]. It also influences economic empowerment rate of community Tourism potential can improve fisher income when they use this tourism potential [38].

Finally, strategy of law and regulation enforcement is the final strategy priority which is considered very determining for the improvement of traditional fishers' welfare. Particularly, fisher group judges that law and regulation enforcement is the second empowerment strategy to improve traditional fishers' welfare by providing clean and healthy life environment quality and by improving life environment preservation of coast and sea. Fisher association has admitted about the limited knowledge about how important to maintain the quality and cleanliness of sea environment and to enforce law and regulation. It is not surprising then if the community is not able enough to keep the sea cleaned. They still perceive that the enforcement for law and regulation is weak because some fishers are still violating law to increase their fish hauling.

\section{CONCLUSION}

Some conclusions and suggestions related to the improvement of traditional fishers' welfare are given:

1. Result of AHP Analysis indicates that priority of variables that influences the improvement of traditional fishers' welfare, according to informant groups, includes environmental change, adaptive behavior, and coastal development, while the priority of indicators include environmental quality, functional adaptive, accessibility, infrastructure, human resource capability, processual adaptive, and environmental services.

2. The strategy priority of coastal development to improve traditional fishers' welfare, with the activities, involves (1) strategy of human resource development with activities such as skill training to support the interest and demand of traditional fishers including that about modern fishing technique, entrepreneurship, and other non fisheries training; (2) strategy of accessibility to capital/investment and business development through activities such as building self-support character among fishers and counseling and founding fisher cooperative; (3) strategy of infrastructure development and environmental management through activities such as fisher infrastructure improvement and environment management of traditional fishers; (4) strategy of tourism development with activities such as establishing integrated tourism and supporting traditional fishers; and (5) strategy of law and regulation enforcement that is used to improve environment and environmental management, and to increase the supply of the fuel for traditional fishers.

Some suggestions in this research are:

1. Environmental quality at coastal area in Manado Bay must be improved by coordination and integration across stakeholders at coastal area in Manado Bay.

2. The participation of traditional fishers to improve welfare shall be the priority in every strategy and program of coastal area development.

3. The transfer of knowledge, technology, and skill to traditional fishers must be intensive with the support of reliable infrastructure.

4. The system and procedure of strategies and programs to improve traditional fishers' welfare shall be optimized based on the demand of traditional fishers.

5. High empathy from parties authorized to improve traditional fishers' welfare must be internalized.

\section{ACKNOWLEDGEMENT}

The author would like to thank to the following institutions: Directorate of Higher Education and Manado State of Polytechnic for funding and supporting the study, and people for helpful comments and suggestions on an earlier draft of this article: Ronny Mamesah, Ir Alvon Jusuf, MBA, Ir Christin Kumajas, Billy Watuseke, and Ir Sumiaty Mokodompit.

\section{References}

[1] D.I.E. Sundah, A. Suman, Soemarno, and P. Kindangen P, How coastal development, environmenta change, and adaptive behavior affects fishermen's welfare? (A study of traditional fishermen from the coastal area of Manado Bay, Indonesia). IOSR-Journal of humanities and social sciences, 17 (4), 2013, 24-34.

[2] F. Siaosi, H. Huang, C. Chuang, Fishery development strategy for developing Pasific Island Countries: Case study of Tuvalu. Ocean and Coastal Management, 66, 2012, 28-35. 
[3] S. Wunas, and J.H Lumain, Dampak Reklamasi Pantai terhadap perubahan Sosial Ekonomi dan Sosial Budaya Penduduk di Kota Manado. Jurnal Penelitian Enjiniring, 9 (3), 2003, 325-330.

[4] F. P. Kalalo, Kebijakan reklamasi pantai dan laut: implikasi terhadap hak masyarakat pesisir dan upaya perlindungannya. Jurnal hukum dan pembangunan, 39 (1), Juni-maret, 2009,102-118.

[5] Badan pusat statistik kota Manado. Manado dalam angka, (Manado: Badan Pusat Statistik, 2011).

[6] E. Sugiharto, Tingkat Kesejahteraan Masyarakat Nelayan Desa Benua Baru Ilir Berdasarkan Indikator Badan Pusat Statistik. Jurnal EPP, 4 (1), 2007, 41-45.

[7] Kusnadi, Konflik Sosial Nelayan: Kemiskinan dan Perebutan Sumberdaya Perairan (Yogyakarta: LKIS, 2002)

[8] Apridar, M. Karim, and Suhana, Ekonomi kelautan dan pesisir (Yogyakarta: Graha Ilmu, 2011).

[9] Kusnadi, Keberdayaan nelayan \& dinamika ekonomi pesisir: Pusat Penelitian Wilayah Pesisir dan Pulau-pulau Kecil (Yogyakarta: Lembaga Penelitian Universitas Jember dan Ar-Ruzz Media, 2009).

[10] N. Nasuchon, and A. Charles, Community involvement in fisheries management: experience in the Gulf of Thailand countries. Marine Policy, 34, 2010, 163-169.

[11] K. H, Mikalsen, and S. Jentoft, From user-froups to stakeholders? The public interest in fisheries management. Marine Policy, 25, 2001, 281-292.

[12] A. Imron, Strategi dan usaha peningkatan kesejahteraan hidup nelayan Tanggulsari Mangunharjo Tugu Semarang dalam menghadapi perubahan Iklim. Jurnal Riptek, 6 (1), 2012, 27 - 37.

[13] B. A. Human, and A. Davies, Stakeholder consultation during the planning phase of scientific programs. Marine Policy, 34, 2010, 645-654.

[14] R. W. Griffin, Management (Boston: Houghton Mifflin Company, 2004).

[15] H. Weihrich, and H. Koontz, Management: A Global Perspective (New York: McGraw Hill International, 1994).

[16] G.R. Terry and L. W. Rue, Principle of Management (Los angeles: Richard D.Irwin Inc, 1992).

[17] M. P. Follet, Dynamic Administration ( New York: Harper and brothers, 1941).

[18] S. H. Purnomo and Zulkieflimansyah, Manajemen Strategi (Jakarta: Fakultas Ekonomi Universitas Indonesia, 2007).

[19] J. D. Hunger and T.L. Wheelen, Strategic Management (Boston: Addison-Wesley. USA, 1996).

[20] D. Faulkner and G. Johnson, The Challenge of strategic management (London: Kogan Page, 1992).

[21] L. G. Hambrick, Implementing Strategy. Journal of Chief executif. 57, 1990, 74-82

[22] H. Mintzberg, "The design school: reconsidering the basic premise of strategic management. Journal of Strategic management. 11 (2), 1991, 171-195.

[23] A. Menon, S.G. Bharadwaj and R. Howell, The quality and effectiveness of marketing strategy: effect of functional and disfunctional conflict in intraorganisational relationship, Journal of Marketing. 24 (4), 1996, 299-313

[24] A. Ferdinand, Marketing strategy making: proses dan agenda penelitian. Jurnal sain pemasaran Indonesia. 1 (1), 2002 , 1-22

[25] P. Varadarajan, Rajan and S. Jayachandran, Strategy content and process perspectives revisited, Journal of the academy of marketing science. 15 (3), 1999, 120-143

[26] Sugiyono, Metode Penelitian Kombinasi (Mixed Methods) (Bandung: Alfabeta, 2012).

[27] Saaty, T.L. Decision Making for Leaders: The Analytical Hierarchy Process for Decisions in Complex World (London: University of Pitsburgh, 1986).

[28] F. Rangkuti, Analisis SWOT teknik membedah kasus bisnis: Reorientasi konsep perencanaan strategis untuk menghadapi abad 21 (Jakarta: PT Gramedia Pustaka Umum, 2005).

[29] P. Hadijanti, Kemiskinan dan Pemberdayaan Masyarakat. Jurnal Pembangunan Masyarakat Islam, 2 (1), $2006,23-34$.

[30] M. Kuncoro, Metode Kuantitatf: Teori dan Aplikasi untuk bisnis dan ekonomi (Yogyakarta: Sekolah Tinggi Ilmu Manajemen YKPN, 2011).

[31] R.E. Bowen, and C. Riley, Socio-Economi Indicators and Integrated Coastal Management. Ocean and Coastal Management, 46, 2003, 299-312.

[32] S.M. Garcia, D.J. Staples, and J. Chesson, The FAO guidelines for the development and use of indicators for sustainable development of marine capture fisheries and an Australian example of their application. Ocean and Coastal Management, 43, 2000, 537-556.

[33] K. Ravik, Pemberdayaan Masyarakat untuk usaha menengah kecil dan mikro (pengalaman empiris di wilayah surakarta, Jawatengah). Jurnal Penyuluh, 3 (2), 2007, 24-34.

[34] T. Pranaji, Penguatan Modal Sosial untuk Pemberdayaan Masyarakat Pedesaan dalam Pengelolaan agroekosistem lahan kering. Jurnal Agro Ekonomi, 2 (2), 2006, 9-20.

[35] A. Suherman and A, Dault, Analisis dampak sosial ekonomi keberadaan Pelabuhan Perikanan Nusantara (PPN) Brondong Lamongan Jawa Timur. Jurnal Saintek Perikanan, 5 (1), 2009, 25 - 30.

[36] N.F. Agus, Keberdayaan dan Strategi Pelaksanaan Penyuluhan Masyarakat Nelayan Kota Bengkulu. Disertasi, Sekolah Pascasarjana, Institut Pertanian Bogor, Bogor, 2009.

[37] Sumaryo, Pemberdayaan Ekonomi Masyarakat dalam Implementasi Tanggungjawab Sosial Perusahaan (Corporate Social Responsibility) oleh PT. GGP di Kabupaten Lampung Tengah, Laporan Penelitian, Jurusan Sosial Ekonomi Pertanian. Fakultas Pertanian. Bandar Lampung, 2008.

[38] B. Aryono, Kajian peran pengembangan pariwisata bahari terhadap kesejahteraan nelayan di pulau karimunjawa dan pulau kemujan kabupaten jepara, Tesis yang dipublikasikan, Program Pendidikan Pasca Sarjana Universitas Diponegoro, Semarang, 2004. 